\title{
CHEMICAL COMPOSITION AND MICROBIAL SAFETY OF PORK MEAT PRODUCTS ORIGINATING FROM HERZEGOVINA
}

\author{
Leona Puljić1, Brankica Kartalovićn , Jozo Grbavac ${ }^{1}$, Marija Jukić- Grbavac ${ }^{1}$, \\ Dragan Kovačević ${ }^{3}$, Jelena Petrović ${ }^{*}$, Krešimir Mastanjević ${ }^{3}$ \\ ${ }^{1}$ Faculty of Agriculture and Food Technology of the \\ University of Mostar, Bosnia and Herzegovina \\ ${ }^{2}$ Scientific Veterinary Institute Novi Sad, Republic of Serbia \\ ${ }^{3}$ Faculty of Food Technology, University of J. J. \\ Strossmayer of Osijek, Republic of Croatia
}

\begin{abstract}
This paper presents the results of chemical composition and microbiological safety testing of dry cured meat products, fermented and semi-dry or pasteurized sausages produced by several meat industries from Herzegovina. In the period from 2016 to 2018, a total of 85 meat products were sampled. These included 20 samples of fermented pork sausages, 10 samples of dry-cured pork loin, 5 samples of dry-cured pork neck and 50 samples of heat-treated sausages. Quality control testing of the samples included determination of meat protein, crude fat, moisture, sodium nitrite and polyphosphates content in sausages, using standard analytical methods. It was confirmed that all analysed samples meet the requirements in terms of chemical composition, level of additives and microbiological safety. In comparison with dry cured meat products and sausages analyses results, with minimum requirements that are set forth in regulations for that product category. The above mentioned suggests that the analysed samples are good quality products and they are in compliance with the regulations.
\end{abstract}

Keywords: dry cured products, sausages, chemical composition, microbiological safety

\footnotetext{
${ }^{1 *}$ Corresponding author: jelena@niv.ns.ac.rs
} 


\title{
HEMIJSKI SASTAV I MIKROBIOLOŠKA BEZBEDNOST PROIZVODA OD MESA SVINJA POREKLOM IZ HERCEGOVINE
}

Leona Puljić1 ${ }^{1}$ Brankica Kartalović ${ }^{2}$, Jozo Grbavac ${ }^{1}$, Marija Jukić- Grbavac ${ }^{1}$, Dragan Kovačević ${ }^{3}$, Jelena Petrović ${ }^{2}$ Krešimir Mastanjević ${ }^{3}$

\author{
${ }^{1}$ Agronomski i prehrambeno-tehnološki fakultet \\ Sveučilište u Mostaru, Bosna i Hercegovina \\ ${ }^{2}$ Naučni Institut za Veterinarstvo Novi Sad, Republika Srbija \\ ${ }^{3}$ Prehrambeno-tehnološki fakultet Osijek, Sveučilište J. J. \\ Strossmayera u Osijeku, Republika Hrvatska
}

\section{Kratak sadržaj}

U ovom radu prikazani su rezultati ispitivanja kemijskog sastava i mikrobiološke ispravnosti trajnih suhomesnatih proizvoda, fermentiranih i toplinski obrađenih kobasica podrijetlom iz više mesnih industrija sa područja Hercegovine. U razdoblju od 2016. do 2018. ukupno je uzorkovano 85 mesnih proizvoda, od toga 20 uzoraka fermentiranih suhih trajnih kobasica od svinjskog mesa, 10 uzoraka svinjske pečenice, 5 uzoraka suhog svinjskog vrata - buđole i 50 uzoraka toplinski obrađenih kobasica. U cilju ispitivanja kakvoće, u uzorcima trajnih suhomesnatih proizvoda i kobasica određena je količina bjelančevina, sirovih masti, vode, te aditiva natrijevog nitrita i polifosfata primjenom standardnih analitičkih metoda. Usporedbom rezultata analiza uzoraka s zakonski propisanim uvjetima, utvrđeno je da svi analizirani proizvodi udovoljavaju propisanim uvjetima, u pogledu kemijskog sastava i mikrobiološke ispravnosti. Svi uzorci kobasica udovoljavali su zahtjevima Pravilnika, u pogledu sadržaja aditiva. Iz svega navedenog možemo zaključiti da su analizirani uzorci proizvodi dobre kvalitete i odgovaraju propisanim zakonskim normativima.

Ključne riječi: trajni proizvodi, kobasice, kemijski sastav, mikrobiološka ispravnost

\section{INTRODUCTION}

Food legislation lays down general principles and requirements for meat products and ensures that only safe products can be placed on the market. 
According to current regulations, the quality of foodstuffs including meat products is determined according to their chemical composition and product specification, i.e., specification sheet. Production process and quality of food products is systematically addressed by relevant legislative and inspection authorities, but it is also in the spotlight of consumers. Increased health awareness and knowledge about food-related risks strongly affects current consumer demand trends. An accurate insurance of the safety of food products requires determination of product composition by application of appropriate chemical and microbiological analyses (Aćimović et al., 2014).

Dry cured meat products are common traditional foods, which have been produced and consumed worldwide over the centuries. They contain a variety of flavours and textures and are considered an important segment of local economy and an essential part of the cultural and gastronomic heritage. Technology of production of dry cured products, regardless of the type, involves salting, drying and ripening procedures (Krvavica et al., 2012). However, the quality of these products relies upon the selection of raw materials and processing technologies. Knowledge and understanding of highly complex chemical reactions in the tissues facilitate improved control of the processing system and the quality of finished products as well. Cured meat products are widely accepted and popular among consumers. However, the adverse effects of dry cured meat products and sausages such as high contents of salt, saturated fats and cholesterol, etc. must not be neglected (Popelka, 2016; Čop, 2016). Traditional manufacturing process might be associated with certain risks related to environmental conditions, hygiene, animal health, welfare on the farms, etc. (Oiki et al., 2016). Sausages are produced by stuffing selected ground mixture (meat, fat tissue, skin, offal, connective tissue and other ingredients) into natural or artificial casings (Kovačević, 2001). Dry fermented sausages are considered products of highest quality. In the region of Herzegovina, such sausages are commonly produced from pork meat, sometimes mixed with certain amount of beef, which undergo fermentation, smoking and drying process. Fermented dry sausages from Bosnia and Herzegovina are usually put on the market under commercial names "kulen", "zimska salama", "srijemska kobasica", "sudžuk" and "čajna kobasica" and a wide range of similar products is also available. According to the Regulation for minced meat, semi-finished meat products and meat products (Anonymous 2013 a,b,; Anonymous 2017) heattreated sausages are defined as meat products manufactured from the mixture of minced meat, mechanically deboned meat, fat and adipose tissue, offal, blood and blood products of different mincing degree and additional nonmeat ingredients. A portion of filling for heat-treated sausages, i.e. meat batter 
or meat emulsion, is shaped into natural or artificial casing, pouch, mold, and subjected to heat treatment - pasteurization with/without smoking or boiling and sterilization. In Bosnia and Herzegovina, heat-treated sausages are marketed as finely minced or roughly minced boiled semi-durable sausages, whole-cut meat sausages or boiled and other heat-treated sausages.

As there is lack of relevant information on meat products manufactured in $\mathrm{B} \& \mathrm{H}$, the aim of this research was to identify basic nutritional parameters and microbial safety of nine different types of semi-dry and dry meat products manufactured in several meat factories from the region of western Herzegovina and sampled over a three-year period. An overview of the results of analyses of chemical composition and microbial safety of finished products from the group of fermented dry sausages, dry cured meat products and heattreated sausages (finely minced boiled, semi-dry, whole-cut meat sausages) is presented. For each sample, the contents of proteins, crude fat and water were determined and the microbial population were determined. Quantification of sodium nitrite and polyphosphates was performed for all the samples from the category of dry fermented and heat-treated sausages. The obtained results were compared with the reference values laid down in the national regulations with the aim to evaluate the quality and microbial safety of meat products as well as to determinate the content of nitrites and polyphosphates (Anonymous 2013a,b,c, 2016, Anonymous 2017; Anonymous 2018a,b).

\section{MATERIAL AND METHODS}

This research was conducted on 85 samples of semi-dry and dry processed meat products manufactured by several meat companies. According to the classification laid down by the Regulations (Anonymous 2013a and 2017), the samples were categorized into five categories - 20 samples of fermented dry sausages ("čajna kobasica" and "zimska salama"), 15 samples of dry cured meat products (dry-cured pork tenderloin and dry-cured pork collar - "budjola"), 10 samples of heat-treated sausages (finely minced cooked sausages - frankfurter), 20 samples of roughly minced cooked sausages ( "kranjska kobasica" and "narodna kobasica") and 20 samples of sausages made of whole cuts of meat ("kuhana šunka" and "pica šunka"). The sampling was performed randomly over a 3-year period (2016-2018) in the territory of western Herzegovina - municipalities of Široki Brijeg, Ljubuški, Grude, Čitluk and Posušje as well as in the city of Mostar.

Sampling and sample preparation were conducted according to the standard procedure (ISO 3100-1:1991). All analyses were performed in the labora- 
tories of the Public Institution "Veterinary Institute Bihac'" applying accredited methodologies. Chemical quality of the samples was determined by quantifying total lipid contents (BAS ISO 1443:2007), moisture contents (BAS ISO 1442:2007) and total protein contents (BAS ISO 937:2007). In sausage samples, nitrite (BAS ISO 2918:2007) and polyphosphate (BAS ISO 13730:2008) contents were determined. Microbial safety of samples was determined by standard BAS ISO methods for detection and/or enumeration: Salmonella spp. (BAS EN ISO 6579-1:2018), E. coli (BAS ISO 16649-1:2019), Listeria monocytogenes applying (BAS EN ISO 11290-2:2018); Enterobacteriaceae (BAS ISO 215282:2013); sulphitoreducing clostridia (BAS ISO 15213:2008); Staphylococcus aureus (BAS EN ISO 6888-1:2008); the counts of aerobic colonies applying (BAS EN ISO 4883-1:2014).

\section{Statistical data analyses}

The results are presented as a mean value \pm standard deviation. Descriptive statistics (minimum, maximum, mean value, standard deviation, variance, modus and median) was calculated for all analysed variables. The data were processed using Microsoft Office Excel 2016 (Microsoft, SAD) software package.

\section{RESULTS}

In dry cured products, water content varied between $29.0 \%$ in dry pork collar and $52.1 \%$ in dry-cured pork tenderloin. Total fat content ranged from minimum value in pork tenderloin (15.5\%) to a maximum of $45.0 \%$ in drycured pork collar. The highest average protein content $(21.8 \%)$ was determined in a dry-cured pork collar "budjola" (Figures 1 and 2). In dry fermented sausages, the highest protein and fat contents were determined in "zimska slama", amounting $29.7 \%$ and $43.4 \%$, respectively. High water content $(27.7 \%)$ was found in "čajna kobasica". The highest protein and fat contents in the group of semi-dry sausages were determined in sausages "narodna kobasica" and "kranjska kobasica" amounting $28.6 \%$ and $53.3 \%$, respectively. Water content ranged between $24.3 \%$ in "kranjska kobasica" and $29.8 \%$ in "narodna kobasica". The average contents of proteins, fat and water in frankfurter sausage were $17.6 \%, 24.1 \%$ and $58.3 \%$, respectively. The analyses of sausages made of whole cuts of meat revealed an average protein content of $13.2 \%$ in cooked ham and $14.7 \%$ in „pizza šunka“, whereas lower fat content $(9.0 \%)$ was determined in „pizza šunka“ and higher moisture content (73.3\%) was found in cooked ham. 


\section{Proteins, fat and water content (\%)}

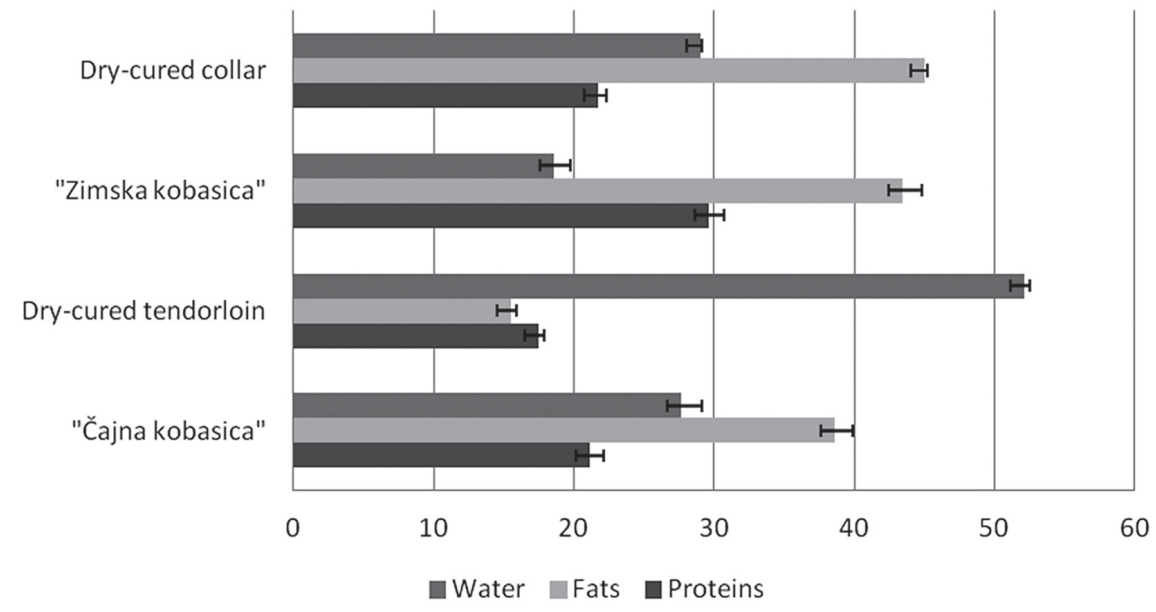

Figure 1. Mean values $( \pm S D)$ of protein, fat and moisture determined in the dry cured products

\section{Proteins, fat and water content (\%)}

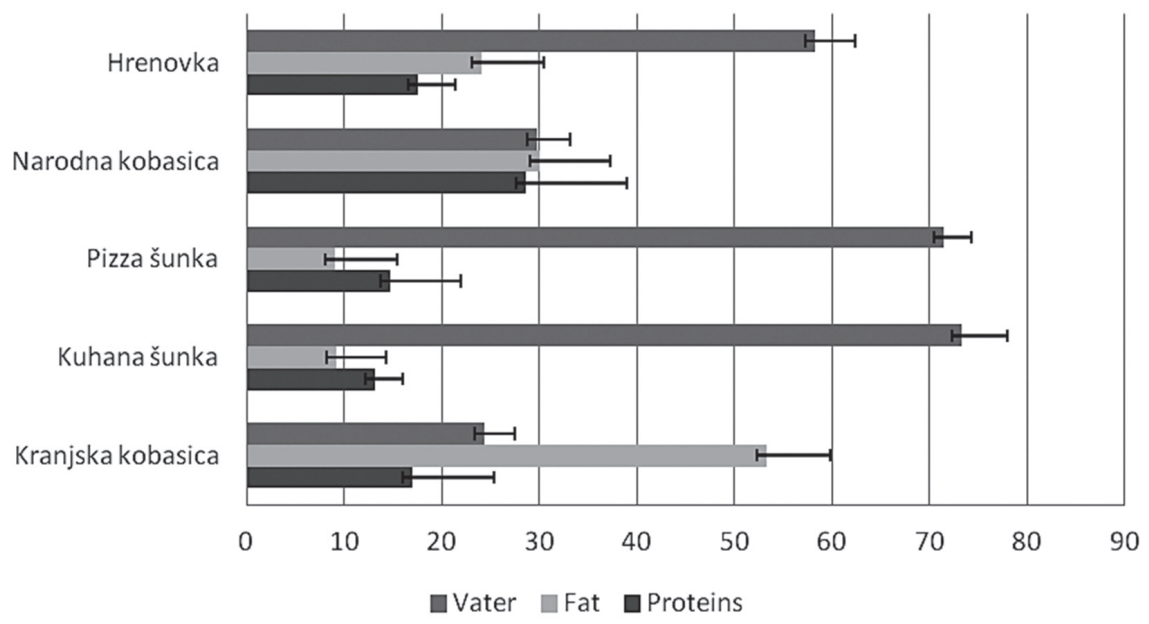

Figure 2. Mean values $( \pm S D)$ of protein, fat and water determined in the semi-dry and pasteurised sausages 
Food additives are used in meat industry with the aim to improve sensory properties of food, enhance processing procedures or extend durability of the products, results are presented in Table 1 . These results revealed high variation of sodium nitrite concentration between dry sausages and heat-treated sausages comparing to low variation between polyphosphates content.

Table 1. Mean values $( \pm S D)$ of sodium nitrite and polyphosphates content

\begin{tabular}{lll}
\hline Product type & Sodium nitrite $\mathrm{mg} \mathrm{kg}^{-1}$ & Polyphosphates $\mathrm{g} \mathrm{kg}^{-1}$ \\
\hline Čajna kobasica & $4.9 \pm 4.5$ & $3.0 \pm 0.6$ \\
Zimska salama & $5.7 \pm 4.3$ & $3.6 \pm 0.4$ \\
Kranjska kobasica & $40.9 \pm 14.9$ & $2,1 \pm 0.2$ \\
Narodna kobasica & $42.3 \pm 15.6$ & $3.4 \pm 0.4$ \\
Frankfurter & $29.2 \pm 8.4$ & $4.2 \pm 0.6$ \\
Kuvana šunka & $37.3 \pm 19.6$ & $2.8 \pm 0.7$ \\
Piza šunka & $31.8 \pm 17.3$ & $3.2 \pm 0.7$ \\
\hline
\end{tabular}

Our research did not reveal the presence of food borne pathogens Salmonella spp., L. monocytogenes in any of the analysed samples. The indicators of process hygiene - total counts of aerobic mesophilic bacteria, Enterobacteriaceae, sulphitoreducing clostridia, E. coli and Staphylococcus aureus and other coagulase positive staphylococci were less than 10 colony forming units per $1 \mathrm{~g}$ products, which is in compliance with the minimum requirements laid down in the Regulation.

\section{DISCUSSION}

Chemical composition of meat products from Herzegovina is similar to industrial products from neighbouring countries, where similar processing technologies are applied (Croatia, Slovenia and Serbia). The water, protein and fat content in dry cured products is typical and comparable with the results for similar types of products from Bosnia and Herzegovina $(\mathrm{B} \& \mathrm{H})$ and Croatia (Pleadin et al., 2013; Pleadin et al., 2017). The fat content in dry fermented sausages in our research is similar with contents in sausages from Croatia and Serbia (38-41\%) (Pleadin et al., 2009; Pleadin et al., 2013; Dučić et al., 2018), but it is lower than average fat content $(40-50 \%)$ in similar, industrialy produced sausages from Spain (Olivares et al., 2010). The average protein content is similar with contents in sausages from Croatia and Serbia (26.2 - 47.9\%) (Pleadin et al., 2009; Pleadin et al., 2013; Dučić et al., 2018). Fat and protein content in 
industrial products in our research is higher than content in traditional homemade product from Croatia (15.4\% and 19.5\%, respectively) (Kozačinski et al., $2008)$. Pleadin et al., $(2009 ; 2017)$ reported somewhat lower contents of proteins $(15.1 \%)$ and fat $(24.6 \%)$ for semi-dry sausages from B\&H, which could be attributed to different recipes used by specific manufacturers (the amount of added bacon, the use of more or less lean meat). The results of this study for sausages made of whole cuts of meat correspond with previously reported results (Pleadin et al., 2009) for similar heat-treated sausages from Croatia.

All the analysed products were in accordance with requirements of the Regulation No. 82/13 (Anonymous 2013a) with regard to their chemical composition. The results of this research suggest that dry sausages are products of highest quality and commercial value due to their ingredients and nutritive value, i.e. the selection of best-quality meat and long ripening period. Compared to semi-dry and cooked sausages, dry products are characterized by lower moisture content.

This research revealed low concentration of sodium nitrite and polyphosphates. Kovačević et al. (2016) and Pleadin et al. (2009) reported somewhat higher values for sodium nitrite (42.0 mg kg-1 and $44.8 \mathrm{mg} \mathrm{kg}-1$ ) for similar products from the category of heat-treated sausages available on Croatian market. Kovačević et al. (2016), Pleadin et al. (2009) and Dučić et al. (2018) reported similar results (7.0 mg kg-1, $5.4 \mathrm{mg} \mathrm{kg-1}$ and 7.1-9.1 mg kg-1) for dry sausages from Croatia and Serbia. These vallues are within values recommended for stability during the storage period (5-15 mg kg-1) (Sindelar and Milkowski 2011). All analysed samples were in compliance with the requirements of the Regulation No 33/18 (Anonymous 2018a) agreed with the European Commission (EC) Regulation No. 1333/2008 (EC, 2008). According to this Regulation, a maximum permitted level for sodium nitrite (mg kg-1) in dry-fermented sausages is $50 \mathrm{mg} \mathrm{kg}-1,100 \mathrm{mg} \mathrm{kg}-1$ for heat-treated sausages, $50 \mathrm{mg} \mathrm{kg}-1$ for dry-cured meat products and $100 \mathrm{mg} \mathrm{kg}-1$ for semi- dry-cured meat products. Maximum permissible level for polyphosphates is $5 \mathrm{~g} \mathrm{~kg}-1$ for all meat products.

From a public health perspective, fermented and heat-treated meat products can be analysed for their technological, biochemical, toxicological, nutritive and other properties. Complex production process and diverse health aspects of fermented meat products require a multidisciplinary approach enabling an insight into potential risks and control thereof (Zdolec, 2016). Meat and meat products are highly suitable medium for microbial growth. Thus, meat products can contain organisms that are responsible for desirable specific taste of fermented products (sensory properties), harmful agents that can 
cause undesired changes of the texture, colour or taste of fermented products as well as pathogens, which can harm the health of consumers. Some of the most important foodborne pathogens that can be found in fermented meat products and heat-treated sausages are Salmonella spp, L. monocytogenes, $S$. aureus and E. coli (De Cesare et al., 2007; Stojanac et al., 2015). Fermented meat products are a food vehicle in the outbreaks usually caused by Salmonella spp. or verocytotoxigenic E. coli (Paramithiotis and Drosinos, 2016). Fermented meat products with a $\mathrm{pH} \leq 4.4$ and water activity (aw) $\leq 0.92$, or with $\mathrm{pH} \leq$ 5.0 and aw $\leq 0.94$ do not enhance the growth of pathogenic bacteria. However, although considered formally safe, the risk still exists and is associated with post-processing contamination - e.g. during slicing or packaging. Regarding the aforementioned, fermented meat products could still be considered potentially risky food. The results of microbiological analyses confirmed the microbiological safety of pork meat products originating from Herzegovina.

\section{CONCLUSION}

According to the results obtained in this research and data from the literature, we can conclude that fermented dry sausages, dry cured meat products and heat-treated sausages have chemical composition similar to products from other parts of B\&H, Croatia, Serbia and Slovenia. The analyses of the obtained results strongly indicate that all product samples are of good quality and in compliance with relevant legislation.

\section{Authors' contributions}

LP, DK and KM made contributions to conception and design of the article, involved in data collection and drafting the manuscript. LP, JG, BK and MJG contributed with data about chemical composition, additive content and microbiological results. JP revised the manuscript critically and together with LP prepared the final draft of the manuscript. All authors read and approved the final manuscript.

\section{Competing interest}

Authors declared no conflict of interests regarding the present paper. 


\section{REFERENCES}

1. Anonymous, 2013a. Regulation of minced meat, semi-finished meat products and meat products [in Bosnian]. Official Gazette of the Bi\&H 82.

2. Anonymous, 2013b. Regulation of minced meat, semi-finished meat products and meat products - Amendment [in Bosnian]. Official Gazette of B\&H' 84.

3. Anonymous, 2013c. Regulation on microbiological criteria in food [in Bosnian]. Official Gazette of B\&H 11.

4. Anonymous, 2016. Regulation on maximal permited of contaminants in food [in Bosnian]. Official Gazette of B\&H 79.

5. Anonymous, 2018a. Regulation on microbiological criteria in food Amendment [in Bosnian]. Official Gazette of B\&H 54.

6. Anonymous, 2018b. Regulation on food aditives [in Bosnian]. Official Gazette of B\&H 33.

7. Aćimović M., Kozačinski L., Njari B., Cvrtila Fleck Ž: Usporedni prikaz propisa o kakvoći mesnih proizvoda. Meso 16, 4, 342-345, 2014.

8. BAS ISO. 2007. Meat and meat products - Determination of total fat content. No 1443.

9. BAS ISO. 2007. Meat and meat products - Determination of moisture content. No 1442.

10. BAS ISO. 2007. Meat and meat products - Determination of nitrogen content. No 937.

11. BAS ISO. 2007. Meat and meat products -Determination of nitrite content. No 2918.

12. BAS ISO: Meat and meat products- Determination of total phosphorus content - Spectrometric method. No 13730, 2008.

13. BAS ISO. 2008. Microbiology of food and animal feeding stuffs - Horizontal method for the enumeration of sulfite- reducing bacteria growing under anaerobic conditions. No 15213.

14. BAS ISO. 2013. Microbiology of food and animal feeding stuffs - Horizontal methods for the detection and enumeration of Enterobacteriaceae - Part 2: Colony-count method. No 21528-2.

15. BAS ISO. 2019. Microbiology of the food chain - Horizontal method for the enumeration of beta-glucuronidase-positive Escherichia coli - Part 1: Colony-count technique at 44 degrees $\mathrm{C}$ using membranes and 5-bromo4-chloro-3-indolyl beta-D-glucuronide. No 16649-1.

16. BAS EN ISO. 2008. Microbiology of food and animal feeding stuffs - Horizontal method for the enumeration of coagulase-positive staphylococci 
(Staphylococcus aureus and other species) - Part 1: Technique using BairdParker agar medium. No 6888-1.

17. BAS EN ISO. 2014. Microbiology of the food chain - Horizontal method for the enumeration of microorganisms - Part 1: Colony count at $30 \mathrm{de}-$ grees $\mathrm{C}$ by the pour plate technique. No 4883-1.

18. BAS EN ISO. 2018. Microbiology of the food chain - Horizontal method for the detection, enumeration and serotyping of Salmonella - Part 1: Detection of Salmonella spp. No 6579-1.

19. Čop M. 2016. Utjecaj Enterococcus faecalis 101 na kakvoću trajnih kobasica iz domaćinstva. Diplomski rad. Veterinarski fakultet Sveučilišta u Zagrebu.

20. De Cesare A., Mioni R., Manfreda G. 2007. Prevalence of Listeria monocytogenes in fresh and fermented Italian sausages and ribotyping of contaminating strains. International Journal of Food Microbiology 12, 124-130.

21. Dučić M., Vranješ D., Baltić M.Ž. 2018. Selected physico-chemical properties of Serbian dry fermented sausages in different meat industries. Meat Technology 59,2, 120-126.

22. EC (European Commission): Regulation on food additives No. 1333, 2008.

23. ISO (International Organisation for Standardization), 1991. Meat and meat products - Sampling and preparation of test samples -Part 1: Sampling. No 3100-1

24. Kovačević D. 2001. Kemija i tehnologija mesa i ribe. Sveučilište Josipa Jurja Strossmayera u Osijeku, Prehrambeno tehnološki fakultet, Osijek.

25. Kovačević D., Mastanjević K., Ćosić K., Pleadin J. 2016. Količina nitrita i nitrata u mesnim proizvodima s hrvatskog tržišta. Meso 2, 18, 40-46.

26. Kozačinski L., Hadžiosmanović M., Cvrtila Fleck Ž., Zdolec N., Filipović I., Kozačinski Z. 2008. Kakvoća trajnih kobasica i češnjovki iz individualnih domaćinstava. Meso 10, 1, 45-52.

27. Krvavica M., Mioč B., Friganović E., Kegalj A., Ljubičić I. 2012. Sušenje i zrenje - temeljni tehnološki procesi u proizvodnji trajnih suhomesnatih proizvoda. Meso14, 2, 138-144.

28. Oiki H., Kimura H., Zdolec N. 2016. Traditional production of fermented meats and related risk. In: Fermented meat products: health aspects. N. Zdolec (ed.). Taylor \& Francis, Boca Raton, USA, 49-57.

29. Olivares A., Navarro, J. L., Salvador, A., Flores, M. 2010. Sensory acceptability of slow fermented sausages based on fat content and ripening time. Meat Science, 86, 251-257.

30. Paramithiotis S., Drosinos E.H. 2016. Foodbone pathogens of fermented meat products. In: Fermented meat products: heaalth aspects. N. Zdolec (ed.). Taylor\&Francis, Boca Raton, USA, 196-227. 
31. Pleadin, J., Perši N., Vulić A., Đugum J. 2009. Kakvoća trajnih, polutrajnih i obarenih kobasica na hrvatskom tržištu. Hrvatski časopis za prehrambenu tehnologiju, biotehnologiju i nutricionizam 4 (3-4), 104-108.

32. Pleadin J., Vahčić N., Perši N., Kovačević D. 2013. Varijabilnost fizikalno-kemijskih i senzorskih svojstava autohtonih mesnih proizvoda između proizvodnih domaćinstava. Meso 15, 2, 122-131.

33. Pleadin J., Vasilj V., Lešić T., Frece J., Markov K., Krešić G., Vulić A., Bogdanović T., Zadravec M., Vahčić N. 2017. Kemijski sastav i pojavnost mikotoksina u tradicionalnim mesnim proizvodima podrijetlom s domaćinstava Bosne i Hercegovine. Meso, 19, 4, 309-316.

34. Popelka P. 2016. Fermented meats composition - health and nutrition aspects. In: Fermented meat products: health aspects. N. Zdolec (ed.). Taylor \& Francis, Boca Raton, USA, 389-416.

35. Sindelar J.J., Milkowski A.L. 2011. Sodium nitrite in processed meat and poultry meats: A review of curing and examining the risk/benefit of its use. American Meat Science Association. AMSA white paper series, No. 3.

36. Stojanac N., Stevančević O., Blagojević B., Davidov I., Stojanac V. 2015. Značaj i kontrola infekcije Salmonella spp. u proizvodnji svinja. Letopis naučnih radova $39,1,58-65$.

37. Zdolec N. 2016. Fermented Meat Products: Health Aspects. N. Zdolec (ed.). CRC Press Taylor \& Francis, Boca Raton, Florida, USA, 572.

Received: 22.11.2019.

Accepted: 29.12.2019. 